\title{
Yenilebilir Film/Kaplamalar ve Su Ürünleri Perspektifi
}

\author{
Fatih KORKMAZ \\ Atatürk Üniversitesi Su Ürünleri Fakültesi, 25240, Yakutiye/ERZURUM \\ (korkmazf@atauni.edu.tr)
}

\section{Geliş Tarihi :08.08.2017}

Kabul Tarihi :22.11.2017

\begin{abstract}
ÖZET: Su ürünleri, sucul yaşam alanından çıarıldıktan sonra depolama, taşıma vb. süreçlerde biyokimyasal değişikliklerin ve mikrobiyal bozulmaların sıklıkla görüldüğ̈̈ çabuk bozulan gıdalar sınıfinda yer almaktadır. Diğger gıdalarda olduğu gibi su ürünlerinde de bakteriyel, enzimatik ve kimyasal bozulma sürelerinin uzatılması için çeşitli ambalajlama ve muhafaza yöntemleri yaygın olarak kullanılmaktadır. Kullanılan bu yöntemler içerisinde en güncel uygulamalardan birisi olan yenilebilir film ve kaplamalar; gıdaları korumanın yanı sıra raf ömrünün uzatılması adına, gıdaların yüzeyinde oluşturulan sürekli-ince tabakalı, gıdayla birlikte tüketilebilen (yenilebilen), doğal hammaddelerden elde edilen ürünlerdir. Yenilebilir filmler ve kaplamalar optimum şekilde hazırlandığında (üretildiğinde) klasik (plastik) bir ambalajın sahip olabileceği bütün özellikleri yerine getirebileceği bir çok araştırmada bildirilmektedir. Yenilebilir film ve kaplamalar uygulanmış gıdalarda (özellikle et ürünlerinde), yağ oksidasyonunun azalması veya engellenmesi, suya ek olarak vitaminlerin, kararma tepkimelerini durduran iyonların, aroma bileșiklerinin ve pigmentlerin ürünlerin içerisinde kalması gibi avantajlar, son dönemlerde bu filmleri oldukça popüler hale getirmiştir. Diğer bir açıdan yenilebilir film ve kaplamalar, plastik ambalajların aksine kanserojen etki riskini azaltmasının yanı sıra geri dönüşüm kolaylığıyla atık sorununu da ortadan kaldırmaktadır. Polisakkaritler, proteinler ve lipitler; yenilebilir filmlerin ve kaplamaların hazırlanmasında genel olarak kullanılan ham maddelerdir. Bu komponentlerin farklı avantaj ve dezavantajları nedeniyle bunlardan bir ya da birkaçı birlikte kullanılarak çeşitli karışımlar ve kompozit filmler oluşturulmaktadır. Bu şekilde film ve kaplamaların gaz, nem-buhar geçirgenlik ve yapışma vb. özellikleri geliştirilmektedir. Bu derleme, öncelikle su ürünlerinde genel olarak kullanılan yenilebilir film ve kaplamalar hakkında genel bilgi vermek amacıyla bu uygulamaların su ürünleri üzerindeki etkin rollerinin araştırılması adına temel bilgiler içeren güncel çalışmalara başvurularak hazırlanmıştır.
\end{abstract}

Anahtar kelimeler: Su ürünleri, yenilebilir filmler ve kaplamalar

\section{Edible Films-Coatings and The Use in Aquaculture}

\begin{abstract}
After the aquatic products have been removed from the aquatic habitat, in the process, it is located in the class of fast-breaking food biochemical changes and microbial deterioration are frequently observed. Various packaging and preservation methods are widely used to extend bacterial, enzymatic and chemical degradation times in aquatic products as well as in other foods. Among these methods, edible films and coatings, which are one of the most recent applications, in addition to sheltering shelf life, shelf life is a product of natural raw materials that can be consumed with renewable (renewable) food with a continuous thin layer formed on the surface of foods. Edible films and coatings are reported in a number of investigations where a plastic (plastic) package can fulfill all the characteristics that it has when it is optimally prepared (as produced). Advantages such as the reduction or inhibition of oil oxidation in edible films and coatings applied (especially in meat products), the addition of vitamins in water, the retention of ions, aroma compounds and pigments in products that stop darkening reactions have recently made these films very popular. In other respects, edible films and coatings, in contrast to plastic packaging, reduce the risk of carcinogenic effects, as well as case of the recycling and elimination of waste problems. Polysaccharides, proteins and lipids; raw materials commonly used in the preparation of edible films and coatings. Due to the different advantages and disadvantages of these components, one or more of them are used together to form various mixtures and composite films. In this way, the film and the coatings have gas, moisture-vapor permeability and adhesion etc. features are being developed. This review is based on a survey of current work that includes basic information on the investigation of the effective role of these applications on aquaculture in order to give general information about edible films and coatings that are commonly used in aquaculture.
\end{abstract}

Keywords; Aquaculture, edible films and coatings.

\section{GíRIŞ}

Yenilebilir ambalajlar; Biyopolimerlerden elde edilen, gıdaların üzerini kapatacak şekilde sarmalayan, et, meyve, sebze ve çikolata vb. gıdaların su kaybını, gaz alışverişini ve lipid oksidasyonunu engelleyen sürekli ince bir tabaka olarak tanımlanabilmektedir.

Tarımsal kökenli bu ambalajlar, cam, teneke, polimer gibi ticari ambalajlama materyallerine alternatif olarak geliştirilmiştir (Akbaba, 2006). Yenilebilir film ve yenilebilir kaplamalar olarak ta ifade edilen ilgili materyaller, doğal ve biyolojik olarak geri dönüşümlü maddelerden yapıldıkları için çevreyi kirletmeyen ve çevrenin korunmasına katkıda bulunan ambalajlardır (Valdez vd., 2014). Bahsedilen ambalajlar suyun yanı sıra antimikrobiyal maddelerin, antioksidanların, aroma bileşiklerinin, pigmentlerin, kararma reaksiyonlarını durduran iyonların ve vitaminlerin ürün içerisinde tutulmasını sağlamaktadır. Ayrıca ürün özelliklerinin muhafazası, depolama esnasinda yapılan hataların minimize edilmesi ve tüketici beğenisine hitap eden bir ürün olmasından dolayı tercih edilmektedir (Cuq vd., 1997; Debeaufort vd., 1998; Akbaba, 2006). Yenilebilir film ve kaplamalar uygulandıkları gidalar ile fonksiyonel ve organoleptik uyum içinde olmalıdır. Bu nedenle bu uygulamaların üretiminde kullanılmak üzere arzu edilen duyusal kalite değerlerine sahip maddelerden de yararlanılabilir. Bu 
şekilde üretilen yenilebilir filmler gidanın renk, lezzet, asitlik, tatlllık ve tuzluluk gibi gida değerlerinin korunabilmesine yardımcı olmaktadır (Sarığlu, 2005). Hem gıda bileşeni hem de ambalaj olarak tanımlanan film ve kaplamaların aşağıda belirtilen özellikleri taşımaları istenmektedir: Biyokimyasal, fizikokimyasal ve mikrobiyal stabilitede yeterlilik, optimum duyusal kalite (kokusuz, tatsiz, renksiz, saydam, berrak), optimum geçirgenlik ve mekanik etkinlik (aşınmaya dayanıklı ve esnek), toksik olmama (gida maddesi ile uyum), çevre kirliliği yaratmama, uygun maliyette hammadde eldesi ve prosesi (Stuchel vd., 1995; Kandemir, 2006). Gıda koşullarını optimize ederek güvenli ve kaliteli gıda eldesi, sadece üretim aşamasında değil, ambalajlama ve depolama aşamalarında çeşitli modifikasyonlarla da sağlanabilmektedir. Depolama ve taşıma aşamalarında gerçekleşen değişimler, gıdaların kalitesi üzerine fazlasıyla etki göstermektedir. Gıda maddesini sabit hale getirmek ve gida kalitesini koruma amacı ile yapılan çalışmalarla birçok fiziksel ve kimyasal işlemler geliştirilmiş̧ir. Bu işlemlere ek olarak depolama ve taşıma koşullarına uygun son ürünün ambalajlanması, kalite özelliklerini korumakta ve raf ömrünü uzatmaktadır (Şahin ve Bayizit, 2008). Tüketicilerin talepleri ve gida endüstrisinin eğilimleri doğrultusunda gida ambalajlarının fonksiyonları her geçen gün geliştirilmektedir. Ambalaj üreticileri gıdayı daha uzun süre taze tutmak üzerinde çalışırken, tüketiciler ise gıdanın tazeliğini paketi açmadan görmeyi istemektedirler (Sürengil ve K1lınç, 2011). Son dönemlerde geleneksel ambalajların özelliklerini geliştirmek amacıyla yapılan çalışmalar yenilebilir film ve kaplama ürünleri üzerinde yoğunlaşmaktadır (Kokangül ve Fenercioğlu, 2012). Bahsedilen yoğunlaşmanın sebepleri; Nem Göçünü engellemesi veya azaltması, mikrobiyal bariyer özellik göstermesi, gazların transferini engellemesi veya azaltması, organoleptik katkı sağlaması, bazı durumlarda maliyeti azaltması, geçirgenliğe etkisi, dayanıklılığa katkısı, müşteri talepleri-sağlık yönü arasındaki ilişkiye pozitif etki ve çevreci bir ürün olmasidır. (Kester and Fennema, 1986; Stuchell and Krochta, 1995; Gennadios vd., 1996; Jeon vd., 2002; Sarıoğlu, 2005; Sathivel, 2005; Antoniewski vd., 2007; Vargas vd., 2008; Fan vd., 2009; Song vd., 2011).

\section{YENILEBİLIR HAMMADDELERI}

Yenilebilir filmler; Polisakkaritlerden, proteinlerden, lipidlerden olmak üzere 3 temel biyolojik maddeden oluşmaktadır (Sarıkuş, 2006).

\section{POLISAAKKARIT ORİJINLI FILMLER}

$\mathrm{Bu}$ maddeler genellikle karasal-sucul bitkilerden ve mantarların hücre duvarlarından elde edilmektedirler. Nişasta (farin/amidon), kitosan ve selüloz türevleri, aljinat, pektin, karegen, nişasta hidrolizatlarl, pullulan, levan ve elsinan bu grupta yer almaktadır. Jel kıvamını asidik ve bazik ortam koşullarına göre almaktadırlar (Krochta and De Mulder Johnston, 1997). Polisakkaritlerin gaz bariyer özelliklerinin iyi olmaları sebebiyle meyve ve sebzelerin kesit yüzeyine yapışabilmektedirler. Fakat genellikle polisakkarit filmler sinırlı su buharı bariyer özelliği göstermektedir (Kester and Fennema, 1986; Baldwin vd., 1995; Gontard and Guilbert, 1996; Raeisi vd., 2014). Buna rağmen, bazı polisakkaritler, yüksek nemli jelatin kaplamaların içine ilave edildiğinde, kısa süreli depolarda örneğin et ürünleri gibi bazı gıdalarda nem kaybını azaltmak için kullanılır. Ayrıca, karboksimetil selüloz filmler, suda çözünebilme özelliği göstermesinden dolayı yenilebilir biyofilm ve türevlerinde düşük maliyetli üretimi gerçekleştirilerek yaygın şekilde kullanılmaktadır (Raeisi vd., 2014).

Aljinat filmler: Aljinatlar, kahverengi alglerden (Macrocystis pyrifera) ekstrakte edilerek elde edilmektedir ve aljinik asitin bir tuzu ve sodyum aljinat filmlerin bir polimeri olarak isimlendirilmektedir (Lu vd., 2009). Su direnci, gida işlemede alginatların en pozitif fiziksel ve mekanik karakteridir (Rhim, 2004).

Pektin: Bitki hücrelerinin orta lamelinde bulunan bir polisakkarittir ve k1smen metil alkol ile esterleşmiş asit zincirlerinden oluşmaktadır (Saldaml1, 1985). Pektinlerden elde edilen pektik kaplamalar iyi bir nem bariyeri değildir. Hurma, kuru üzüm ve incir gibi kurutulmuş meyveler, iyi bir görünüş ve yapı açısından önemli olan kritik nem miktarının korunması amacıyla pektinden oluşan yenilebilir filmlerle kaplanmaktadır. Ayrıca yeşil bitkilerin uzun süre yeşil renkte kalmasını sağlamak ve müşteri ilgisini çekmek amacıyla kullanıldığında olumlu sonuçlar vermektedir (Baldwin vd.,1995; Placido vd., 2015).

Karegen: Kirmiz1 deniz yosununun bir ekstraktıdır. Ekstrakt özelliği yosunun cinsine göre değişmektedir. Bahsedilen ekstraktlar hidrokolloid gıda endüstrisinde jelleştirme, inceltme ve stabilize etme özellikleri nedeniyle gıdaların kaplanmasında kullanılmaktadır (Kester and Fennema, 1986; Baldwin vd., 1995; Trius and Sebranek, 1996). Ayrıca, karegenlerin farklı konsantrasyonlarda nişasta karıştırılıp biyofilm uygulamalarında birlikte kullanılmasıyla, nem emiliminde ve mekanik özelliklerde daha etkili olduğu ve daha iyi sonuçlar alınabileceği bildirilmektedir (Abdou vd., 2014). 
Nişasta: Ticari boyutta yaygın bulunabilmesi ve uygun özelliklerde olması nedeniyle gıda paketlemede en etkili olabilen filmler nişastadan elde edilmektedir (Valdez vd., 2014). Nişasta kurutulmuş ürünler, jelibon ve karamellerle kümeleşme ve yapışmanın önlenmesi, patates cipsi, şekerleme ve pastacılık ürünlerinde yağ bariyerleri, badem, findık ve taze dilimlenmiş elmalarda oksijen bariyeri olarak kullanılmaktadır (Korchta and De Mulder-Johnson, 1997). Genellikle \%25 amiloz ve amilopektinden oluşmakla birlikte \%85 amiloz içeren mutant nişastalarda üretilmektedir. Bunlar çeşitli katkılarla beraber kurutulmuş erik, hurma, kuru üzüm gibi gıdalarda yenilebilir karbondioksite karşı yarı geçirgen bir özellik göstermekle birlikte, oksijen açısından iyi bir bariyerdir (Baldwin vd.,1995).

Dekstrinler: Nişastanın bazı bakteriler tarafından sindirilmesiyle oluşan yapılardır. Son dönemlerde yenilebilir biyofilm kaplama çalışmalarında komponentlerle birlikte kullanılmaktadır (Khanedan vd., 2013). Koruyucu kaplama olarak parça etlerde kullanılmakta ve su geçirgenliğine karşı, nişastalara göre 2-3 kat daha fazla direnç göstermektedir (Kester and Fennema, 1986).

Kitosan: Doğal olarak katyonikbipolimer olan kitinden asetillendirilerek elde edilen bir maddedir. Kitin, selülozdan sonra en çok rastlanılan polisakkaritlerdendir (Baldwin vd., 1995). Kitozan filmler, iyi oksijen bariyerleridir (Korchta and De Mulder-Johnson, 1997). Ayrıca geniş çapta mikoorganizmalara karşı antimikrobiyal etki gösteren kitosanlar; mantar, gram pozitif ve gram negatif bakterilere karşı da ekstra direnç göstermektedir (Lim and Hudson, 2003; Shahidi and Abuzaytoun, 2005; Augustini and Sedjati, 2007; Mohan vd., 2012) aynı zamanda yeşilbiber, salatalık ve domatesin olgunlaşmasını geciktirmek ve raf ömrünü uzatmak için de kullanılmaktadır (Gontard and Guilbert, 1996; Lerdthanangkul and Krochta, 1996).

Selüloz türevleri: Karboksimetil selüloz, metil selüloz, hidroksipropil metil selüloz ya da hidroksipropil selüloz olabilir (Saldaml,, 1985; Kester and Fennema, 1986). Bunlar yapisındaki polimer zincirlerin karakterlerinden dolayı iyi bir film oluşturmaktadır (Baldwin vd., 1995). Karboksiselüloz, suda çözünebilmektedir. Bu özelliğine ek olarak farklı kaynaklardan elde edilmesinin yanı sıra ucuz maliyetle üretilmesiyle spesifik bir özellik göstermektedir (Raeisi vd., 2014).

Pullulan, Levan ve Elsinan: Ekstraselüler mikrobiyal polisakkaritlerden olan pullulan, levan ve elsinan; kokusuz, berrak filmler oluştururlar. Pullunan filmler neme karşı çok duyarlıdır ve yüksek bağıl nemde vizkozlaşırlar. Buna rağmen bu filmler düşük bağıl nemde iyi bir oksijen bariyer özelliği göstererek, gıdanının raf ömrünün uzatılması amacıyla kullanılmaktadır (Gontard and Guilbert, 1996; Krochta and De Mulder-Johnston, 1997).

\section{PROTEIN ORIJJINLİ FILMLER}

Yenilebilir filmler içerisinde, en etkili olan filmler protein orijinli filmlerdir. Koruyucu özellik bakımından lipid ve polisakkarit filmlere göre en yüksek koruyucu özellik, protein filmlerde bulunmaktadır (Shatalov vd., 2014). Ayrıca protein kaplamalar nem, oksijen ve karbondioksit kaybına karş1 bariyer özellik göstermektedir. Genel olarak meyve-sebze ve et ürünlerinin kaplamalarında kullanılan proteinler iyi film oluşturmalarından dolayı tercih edilmektedir. Kolajen, jelatin, zein, kazein, soya proteini ve buğday gluteni vb. maddeler bu grupta yer almaktadır. Bu filmler mikrobiyal ve kimyasal açıdan gıdaların bozulmasını geciktirmek amaciyla kaplama boyutunda uygun olan; üç boyutlu şekil, hidrofobik özellik, kristalize olması, yüzey yükü ve moleküler boyut barındırmaktadır. (Lee, 2003).

Kolajen: Omurgalı hayvanlarda temel protein yapısını oluşturmaktadır. Ayrıca biyofilm kaplamalarda en uyumlu (biyo uyum) yenilebilir biyofilm olarak göze çarpmaktadır. Balık kılçıklarından, omurgalarından, deri ve pullarından elde edilen kolajen biyofilmlerin dikkat çeken en önemli özellikleri biyo uyumluluk ve düşük antijenlik göstermeleridir (Yamamoto vd., 2014). Balık kolajeni, deri ve film endüstrilerinde geniş bir uygulama yelpazesine ayrıca balık kolajen amino asidi içeriği nedeniyle de daha düşük termal stabiliteye sahiptir (Noorihashemaba vd., 2015).

Jelatin: Çüzünebilir protein olarak bilinen jelatin, balık derisi ve kemiklerinin kolojenininden termal denatürasyon ile üretilmektedir. Termal olarak tersinir oluşumu, jelatinin çok ilginç bir özelliğidir. Soğuk suda şişer ve $40{ }^{\circ} \mathrm{C}$ ise çözünür özelliktedir. Son dönemlerde, jelatinler film ve kaplama gibi kullanım özelliklerinin yanı sıra yenilebilir biyofilm olarak göze çarpmaktadır (Jahani vd., 2014). Sebze orijinli birçok hidrokolloidin tersine jelatinin jel oluşturma özelliği pH' ya bağımlı değildir ve reaktiflere (şeker, tuz, diğer katyonlar) ihtiyaç duyulmaktadır.

Süt proteini filmi: Süt proteinleri, direkt süt ve indirekt süt ürünlerinden elde edilmektedir. $\mathrm{Bu}$ ürünlerin en önemli bileşenleri, fizikokimyasal ve moleküler özellikleri bakımından değişkenlik gösteren kazein, peynir altı suyu proteini ve kesilmiş sütün suyu proteinidir. Süt proteini orijinli filmler, gıdalar üzerinde bir başına kullanılabilecekleri gibi 
diğer film materyalleri ile belli miktarlarda karıştırılarak ta uygulanabilmektedirler.

Süt proteinleri, kalsiyum kazeinattan daha yüksek seviyelerde antioksidan özellik göstermektedir. Bu özellik proteinlerdeki amino asit kompozisyonunun farklılığından kaynaklanmaktadır. Sütte yer alan laktozun antioksidan aktiviteyi yükselttiği öngörülmektedir. Çeşitli maddelerle birleştirilen süt proteinleri çeşitli işlenmiş gıdalar üzerinde lipid peroksidasyonunu ve hidroperoksit oluşumunu azaltmak için kullanılmaktadır (Tien vd., 2000).

Kazein: Yalnızca süte has bir protein olan kazein, kendine özgü molekül ağılığı, izoelektrik noktası ve aminoasit kompozisyonu olan $\alpha$ s1-, $\alpha$ s2-, $\beta$ ve $\kappa$-kazein şeklinde dört temel bileşenden oluşarak $20^{\circ} \mathrm{C}^{\prime}$ de $\mathrm{pH} 4.6^{\prime}$ da karakterize edilmektedir (Dursun ve Erkan, 2009; Dhanapal vd., 2012). Kazein orijinli filmlerin, yüksek besin değeri, çok iyi duyusal özellik göstermesi ve gıdaları çevresel faktörlerden koruması gibi artılarının olması; gidalarda uygulanmasında ürünü cazip hale getirmektedir. Kazeinlerin yapısal özelliği ve amino asit bileşimleri nedeniyle elektrostatik interaksiyonlar, hidrojen bağları ve hidrofobik olması gibi ekstralar, kazein orijinli yenilebilir filmlerin oluşumunda etkili olmaktadır. Kazein filmlerin degradasyonu ile ilgili fazla bilgi olmamasıyla birlikte, makromoleküllerden yapılan filmlerin bakterilerce ayrıştırılabildiği öngörülmektedir (Sallam vd., 2004; Dursun, 2012; Robertson, 2013).

Peynir Altı Suyu Proteinleri: Peyniraltı suyu, peynir üretimi esnasında kazeinin çökerek ayrılmasından sonra elde edilen kısımdir. $\mathrm{Bu}$ proteinler toplam süt proteinlerinin \%20'sini meydana getirmektedir ve bovine serum albumin, $\alpha$ laktalbumin, immünoglobulinler, $\beta$-laktoglobulin ve proteoz-pepton'lar şeklinde 5 farklı fraksiyonu içermektedir (Polat, 2007).

Peyniraltı suyu protein filmleri, sahip oldukları polar kısımların etkisiyle çok iyi bir oksijen bariyeridir. İyi bir bariyer olması, et ve balık gibi gıdaların korunmasında, meyve ve sebzelerdeki oksidatif kaynaklı renk değişimlerinin önlenmesinde oldukça önemlidir (Debeaufort vd., 1998; Sallam vd., 2004; Park, 2010).

Misır proteinleri: $\mathrm{Bu}$ proteinler çözünürlüklerine göre, albümin, globülin, zein ve glutelin olmak üzere dört grupta toplanmıştır. Bunlardan yalnızca zein ticari olarak üretilmektedir.

Zein: Misir endosperminde bulunan bir prolamin proteinidir ve sadece sulu alkollerle çözünür olmasından dolayı sıra dışı protein olma özelliği taşımaktadır (Krochta, 2002). Zein proteininden hazırlanan yenebilir filmlerin kırılgan yapıda olmalarından dolayı öncelikle plastikleştirilmektedir. $\mathrm{Bu}$ filmler, kullanıldığı gidalarda parlak, sert ve mikroorganizma etkinliğini engelleyen koruyucu bir tabaka meydana getirmektedir. Zein kaplamalar çeşitli gıdalar üzerinde koruyucunun koruyucusu görevi görmektedir (Akbaba, 2006).

Soya sütü: Soya sütü ve soya proteininden Uzakdoğu ülkelerinde yaygın olarak yenilebilir filmler üretilmektedir. (Gennadios and Welder, 1991). Soya protein izolat1, ham materyal olarak filmlerin yapımında fazlaca kullanılan en önemli protein orijinlerinden birisidir. Ayrıca biyolojik olarak parçalanabilen biyo bozunur, çevre dostu bir üründür. Film ve hava arasında protein polimerizasyonu ve solvent ektraksiyonu aracılığıyla film oluşumunun gerçekleştiği düşünülmektedir (Temiz ve Yeşilsu, 2006).

Gluten: Buğday nişastası eldesinde oluşan bir yan üründür. Seçici gaz bariyer özelliği vb. ekstralarının yanı sıra kauçuk benzeri mekanik yapıya sahip filmler buğday gluteninden üretilmektedir (Temiz ve Yeşilsu, 2006). Oksijen ve karbondioksit için iyi bir bariyer oldukları için mekanik özelliklerinin polimerik filmlerle mukayese edilebilir olduğu belirtilmektedir (Butt and Sultan, 2013). Buna rağmen bu filmler, hidrofilik olmaları nedeniyle yüksek su geçirgenliğine sahiptir (Baldwin vd., 1995).

Ayçiçeği proteini filmi: Hayvan yemi olarak kullanılan ayçiçeği yağı keki, yağ üretiminde açığa çıkan ucuz bir protein kaynağıdır ve \%30 oranında protein içermektedir (Orliac and Silvestre, 2003). Söz konusu yöntemlerle üretilen izolatın film oluşturma kapasitesine bakıldığında; protein çözünürlüğünün, plastikleştiricilerin seçiminin ve bazların ayçiçeği protein filminin mekanik özellikleri üzerinde etkili olduğu bildirilmiştir (Ayhllon-Meixueiro vd., 2008). Plastikleştiricilerden gliserolun kırılmaya karşı en büyük direnci gösterdiği, trietilen glikol en yüksek gerginliği yansıttığı bildirilmiştir (Orliac and Silvestre, 2003).

Bezelye proteini filmi: Yüksek besin değeri ve fonksiyonel özelliklerinden dolayı gıda endüstrisinde sıkça kullanılan bezelye, baklagil familyasında yer alan protein kaynaklarından birisidir. Kurutulmuş formlarına bakıldığında genel olarak protein (\%27), karbonhidrat (\%35) ve çok az miktarda da lipid içerdiği görülmektedir (Temiz ve Yeşilsu, 2006).

Pamuk tohumu proteini filmi: Pamuk tohumu unu orijinli çözeltilerin protein izolatlarının aksine, film oluşturma hususunda gerekli koşulların belirlenmesi oldukça güçtür. Nedeni ise ham materyalin (karbonhidrat, protein, lipid, kül, selüloz gibi.) oldukça kompleks oluşudur (Temiz ve Yeşilsu, 2006). Termal ve mekaniksel analizlere göre bu proteinlerinin özellikleri üzerinde gliserol iki farklı 
etkiye sahiptir. Plastikleștirici olması ilk etki, diğeri ise gliserolün fazla miktarda karıştırılmasıyla termal denatürasyonu önleme adına daha stabil hale gelmesidir (Grevellec vd., 2001).

Yerfistığı proteini filmi: Biyopolimerik filmler adına yerfıstıkları önemli bir bileşiktir. Yerfıstığının tohumu \%22-33 protein ve \%45 lipid bulundurmaktadır. Fakat bu tohumların aflatoksinle etkileşime girmesi sonucu büyük oranda ürün kayıpları, düzensiz hava şartları ve uygun olmayan işleme metotları (kızartma vb.) ürünün kalitesinin ve hayvan yemi şeklinde kullanımının azalmasına sebep olmuştur. Neticesinde insan tüketimine sunulamayan yerfistığı tohumlarındaki proteinler farklı kullanım alanlarında değerlendirilerek yenilebilir filmler üretilmiştir. (Liu vd., 2004).

Pirinç proteini filmi: Yüksek seviyede hipoallerjenik olması ve besin değerinin çok seviyelerde görülmesi pirinç proteinlerini spesifik kılmaktadır. Shih (1998), pirinç kepeği proteini/pirinç proteini ile pullulan maddesinin birleştirilmesiyle elde edilen dispersiyonların kurutularak pirinç orijinli yenilebilir filmlerin hazırlanması ve karakterizasyonu hususunda çalışıldığını bildirmişlerdir. Pirinç öğütme işlemiyle üretilen pirinç kepeği, besin değeri yüksek ve protein içeriği fazla olan atık olarak kullanılmayan bir yan üründür. Film eldesindeki solüsyonların pH'larının farklı pirinç kepeği protein filmlerinin fiziksel ve kimyasal özellikleri üzerine etkili olduğu tespit edilmiştir (Adebiyi, 2006; Dursun ve Erkan, 2009).

\section{LIPIDD ORİJINLII FİLMLER}

Gıdaların yağ ile kaplanması, taze ürün ve şekerleme ürünleri için eskiden beri uygulanmaktadır. Lipid filmler ve mumlar, özellikle taze ürünlerin yüzeyinde nem kaybını azaltmak için kullanılmaktadır. Ayrıca hidrofobik özellik göstermektedir (Morillon vd., 2002). Bu kaplamalar meyvelerde yumuşak çürüme gibi küf bozulmalarını da önlemektedir (Kester and Fennema, 1986). Meyve ve sebzelerde dış kaplama olarak kullanılan lipidlerin nem bariyer özellikleri iyidir. Buna rağmen yüksek depolama sıcaklıklarında anaeorobik şartlara yol açabilirler ve hidrofilik özellik gösteren kesit yüzeyine yapışmazlar (Baldwin vd., 1995). Bu grupta, asetilenmiş monogliseritler, doğal mumlar ve surfektantları içeren çeşitli yağ bileşikleri koruyucu kaplama olarak kullanılmaktadır. Asetillenmiş monogliseritlerinin asetilasyon derecesi arttıkça bariyer özellikleri iyileşmektedir. Asetillenmiş monogliserit filmlerin su buharı geçirgenliği, pek çok polisakkarit filmden daha az olmasına karşın, etil ve metil selülozun geçirgenlik değerlerinden daha yüksektir. (Kester and Fennema, 1986). Yenilebilir mumların su buharı geçirgenliği diğer filmlerden daha azdır. Ayrıca, parafin, balmumu, carnauba ve candelilla gibi mumlar meyve ve sebzelerin kaplanmasında kullanılmaktadır (Kester and Fennema, 1986; Hagenmaier and Baker, 1994; Gontard and Guilbert, 1996).

\section{SU ÜRÜNLERİNDEKİ UYGULAMALAR}

Balık ve diğer su ürünleri $\mathrm{pH}$, su aktivitesi ve protein tabiatında yer almayan azot değerlerinin yüksek seviyelerde olmasından dolayı mikrobiyolojik bozulmaya karşı hassas olup, yağ oranı yüksek sucul ürünlerde oksidasyon da görülebilmektedir (Can ve Patır, 2012.) Bütün gıdalarda görüldüğü gibi sucul ürünlerde de bozulmanın önüne geçilmesi veya geciktirilmesi adına günümüzde farklı işleme, ambalajlama vb. yöntemlere başvurulmaktadır. Yenilebilir film ve kaplamalar son dönemlerde bu yöntemler arasında önemli bir yer tutmaktadır. Literatür araştırması yapıldığında; farklı orijinli polisakkarit, protein ve lipitlerden elde edilen yenilebilir film ve kaplama çalışmalarının su ürünleri üzerinde kalite korunumuna pozitif etkide bulunduğu ve dolayısıyla raf ömürlerinde artışlara neden olduğu görülmektedir.

Alak vd. (2010)'de, kitosan kaynaklı filmlerin antimikrobiyal özelliğinden dolayı su ürünlerinde raf ömrünün artırılmasında uygulanabileceğini bildirmişlerdir. Jiang vd. (2010), balık derisinden üretilen jelatine potasyum sorbat ve sodyum tripolyfosfat ekleyerek hazırladıkları filmlerle karidesleri kaplamışlar ve neticesinde kontrol grubuna (kaplanmayan grup) kıyasla filmlerin toplam bakteri ve psikrofil bakteri gelişimleri bakımından daha etkili olduğunu bildirmiştir. Peynir altı suyu proteini orijinli filmlerin, balıklar üzerinde iyi bir su ve oksijen bariyeri etkisi oluşturmasına rağmen, çeşitli antimikrobiyal maddelerle birlikte kullanıldıklarında mikrobiyal azalma üzerinde daha fazla etki göstereceği, Motalebi vd. (2010) tarafından bildirilmiştir. \%1'lik kekik yağı, karanfil yağı ve sarımsak yağı ile elde edilen gluten kaplamaların dumanlanmış alabalık (O. mykiss) filetolarında uygulanarak soğukta muhafazası sonrasında gluten kaplamaların (gluten ve antimikrobiyal içerikli) mikrobiyal ve duyusal bozulma sürelerini uzattığ ayrıca, kekik yağı katkılı gluten kaplamaların lipit oksidasyonunda olumlu sonuçlar verdiği rapor edilmiştir (Akçay, 2012). Tammineni vd. (2013), patates kabuğu atıkları ile hazırladıkları filmlere kekik yağı ilave ederek, soğuk dumanlanmış somon balığınında (Salmo salar) kullanmışlardır. Neticesinde yă konsantrasyonunun artışı ile su buharı geçirgenliğinin azaldığını ayrıca $L$. Monocytogenes türünün inhibe edildiğini belirtmişlerdir. Farayde vd. (2013), nişasta/jelatin filmlerin işleme metotlarını karşılaştırdıkları bir çalışmada, gliserol ve sorbitolü kullanarak çeşitli fiziksel özellikleri incelemiş, yapıştırıcı materyallerin 
ve uygulanan işleme proseslerinin filmlerin yapısal ve mekanik özellikleri üzerinde etkili olduğunu rapor etmişlerdir. Utami vd. (2014), zerdeçal ve karaçalı esansiyel yağlarını katkı maddesi olarak kullandıkları manyok (Manihotes culenta) nişastasından ürettikleri biyofilmlerlerin, alabalık filetolarının raf ömürlerinde artışa neden olduğunu bildirmişlerdir. Ayva müsilajlı yenilebilir ambalajların, buzdolabı şartlarında Gökkuşağı alabalığı (O. mykiss) filetoları üzerinde oksidasyon seviyesinde ve $\mathrm{pH}$ değerlerinde azalmalara sebep olduğu kaydedilmiştir (Joukia vd., 2014). Ariaii vd. (2014), \%15 içerikli karanfil esansiyel yağı aljinat/karboksil metil selüloz kaplamaların gümüş sazanı (Hypophtalmichthy smolitmc) filetoları üzerinde mikrobiyal gelişimi yavaşlattığını bildirmiştir. Çeşitli baharatla birleştirilmiş nişasta bazlı yenilebilir filmlerin beyaz karideslerin kaplanarak raf ömrünün belirlenmesi üzerine yapılan çalışmada, karanfil yağı ve tarçın yağı ile zenginleştirilmiş nişasta filmlerin, mikrobiyal gelişimde ve lipid oksidasyonunda azalmalara, dolayısıyla karideslerin raf ömrünün uzamasına neden olduğu kaydedilmiştir (Meenatchisundaram vd., 2016). İki farklı ambalaj malzemesinin taze somonların (Salmo salar) kalitesi üzerine antimikrobiyal performansının değerlendirildiği çalışmada, karvakrol-lizozim ultra ince filmlerin mezofilik ve psikrofilik bakteri sayısında azalmalara neden olduğu bildirilmiştir (Rollini vd., 2016). Choulitoudi vd. (2017), Dumanlanmış yılan balığg (Anguilla anguilla) filetolarının oksidatif ve mikrobiyolojik stabilitesini arttırmak için biberiye özleri ile zenginleştirdikleri yenilebilir kaplama uygulamasının, +200-800 ppm (karboksil metil selüloz+ biberiye film kaplama) aralığında antioksidan etki gösterdiğini ayrıca mikrobiyal açıdan TMABS, Pseudomonas spp. ve laktik asit bakterileri gelişiminde azalmalara sebep olduğunu bildirmiştir. Yıldız, (2017)'da, tarçın yağı ile zenginleştirdiği kitosan kaplamaları kullanarak gökkuşağı alabalığı (O. mykiss) filetolarının besin kompozisyonuna etkisini araştırdığı çalışmasında, filmlerle kapladığı grupta protein değerinin daha yüksek olduğunu rapor etmiştir.

\section{SONUÇ}

Günümüzde gıdaların raf ömrü ile ilgili çalışmaların birçoğunun, yenilebilir biyofilm uygulamaları ve gıda kaplamaları üzerinde yoğunlaştığı görülmektedir. $\mathrm{Bu}$ yoğunlaşmaların aksine biyofilm ve kaplama uygulamalarının birçoğunda bazı argümanlarda eksiklikler görüldüğü aşikardır. Bilimsel ve sanayi boyutunda detaylı bir araştırma yapıldığında bu argümanlar içerisinde ticari hususta optimum koşulların sağlanamadığı görülmektedir. Diğer gıda sektörlerinde olduğu gibi $\mathrm{su}$ ürünleri sektöründe de, sanayi boyutunda yenilebilir ambalaj objelerinin kullanım alanını yaygınlaştırmak için ideal film ve kaplama malzemelerinin seçimi, ilgili proseslerin modernizasyonu-optimizasyonu, sanayiye modifikasyonunun sağlanması ve en önemlisi sağl1kmaliyet dengesi kurularak daha fazla araştırmanın yapılması gerektiği düşünülmektedir.

\section{KAYNAKLAR}

Abdou, E. S., Osheba, A. S., Sorour, M. A., 2014. Effect of Chitosan and Chitosan-Nanoparticles as Active Coating on Microbiological Characteristics of Fish Fingers. International Journal of Applied Science and Technology 2 (7), 158-169.

Adebiyi, A. P., Adebiyi, A. O., Jin, D.H., Ogawa, T., Muramoto, K., 2008). Rice bran proteinbased edible films, International Journal of Food Science and Technology, 43:476-483.

Akbaba, G., 2006. Yenilebilir ambalajlar, Bilim ve Teknik Dergisi, 30-32.

Augustini, T. W., Sedjati, S., 2007. The effect of chitosan concentration and storage time on the quality of salted-dried Anchovy (Engraulis encrasicolus) Journal of Coastal Development 10(2), 63-71.

Akçay, S., 2012. Antimikrobiyal Madde İçeren Yenilebilir Filmlerin Dumanlanmıs Balığın Kalitesine Etkisi. Yüksek Lisans Tezi, İstanbul Üniversitesi, Fen Bilimleri Enstitüsü, Su Ürünleri Avlama ve İşleme Teknolojisi Anabilim Dalı, Ankara.

Alak, G., Aras Hisar, S., Hisar, O., Kaban, G., Kaya, M., 2010. Microbiological and chemical properties of bonito fish (Sarda sarda) fillets packaged with chitosan film, modified atmosphere and vacuum. Kafkas Üniversitesi Veteriner Fakültesi Dergisi 16 (Suppl-A):73-80.

Antoniewski, M. N., Barringer, S. A., Knipe, C. L., Zerby, H. N., 2007. Effect of A Gelatin Coating on The Shelf Life of Fresh Meat, J Food Sci, 72(6): 382-387.

Ariaii, P., Tavakolipour, H., Rezai, M., Elhami, R. A., 2014. Properties and Antimicrobial Activity of Edible Methylcellulose Based Film Incorporated with Pimpinella Affinis Oil. European Journal of Experimental Biology, $4(1) ; 670-676$

Ayhllon-Meixueiro, F., Vaca-Garcia, C., Silvestre, F., 2008. Biodegradable films from isolate of sunflower (Helianthus annuus) proteins, Journal of Agricultural and Food Chemistry, 48(7): 3032-3036.

Baldwin, E. A., Nisperos-Carriedo, M. O., Baker, R. A.,1995. Edible Coatings for Lightly Processed Fruits and Vegetables. HortScience, Alexandria, v. 30, n. 1, p. 35-38.

Butt, M. S. and Sultan, M. T., 2013. Selected functional foods for potential in diseases treatment and their regulatory issues. Int J Food Prop. 16: 397-415

Can, Ö. P., Patır, B. 2012. Kitosan kaplamanın gökkuşağı alabalığı (Oncorhynchus mykiss, W. 1792) filetolarının raf ömrü üzerine etkisi. Türk Mikrobiyoloji Cemiyeti Dergisi 42(4):148-154.

Choulitoudi, E. Ganiari, S. Tsironi, T. Ntzimani, A. Tsimogiannis, D. Taoukis, P. Oreopoulo, V., 2017. Edible coating enriched with rosemary extracts to enhance oxidative and microbial stability of smoked eel fillets. Food Packaging and Shelf Life. 2017-12,107-103.

Cuq, B., Gontard, N., Cuq, J.L., Guilbert, S., 1997. Selected Functional Properties of Fish Myofibrillar Protein-Based Films As Affected By Hydrophilic Plasticizers. J Agric Food Chem, 45; 622-626

Dhanapal, A., Sasikala, P., Rajamani, L., Kavitha V., Yazhini. G., Banu, M.S., 2012. Edible films from polysaccharides. Food Science and Quality Management 3: 1-10. 
Dursun, S., ve Erkan, N., 2009. Yenilebilir protein filmler ve su ürünlerinde kullanımı. Journal of Fisheries Science 3(4): 352-373.

Dursun, O. S., 2012. Dumanlanmış Balıkların Kalite ve Raf Ömrü Üzerine Yenilebilir Protein Film Kaplamanın Etkisi. Doktora Tezi, İstanbul Üniversitesi, Fen Bilimleri Enstitüsü, Su Ürünleri Avlama ve İşleme Teknolojisi Anabilim Dalı, İstanbul.

Debeaufort, F., Gallo, J.A.Q., Voilley, A., 1998. Edible films and coatings: tomorrow's packagings: a review. Critical Reviewers in Food Science 38(4): 299-313.

Fan, W., Sun, J., Chen, Y., Qiu, J., Zhang, Y. And Chi, Y., 2009. Effects of chitosan coating on quality and shelf life of silver carp during frozen storage. Food Chemistry 115(1): $66-70$.

Farayde, M., Fakhouri, D. C., Yamashita, F., Martelli, S. M., Jesus, R. C. Alganer, K., Collares-Queiroz, F. P., Innocentini-Mei, L. H., 2013. Comparative Study of Processing Methods For Starch/Gelatinfilms. Carbohydrate Polymers, 95(2); 681-689.

Gennadios, A. and Welder, C. L., 1991. Cereal Foods World 36, 1004-1009.

Gennadios, A. and Hanna, M., 1996. Application of Edible Coatings on Meats, Poultry and sea foods, Lebensm-Wiss. U.-Technol, 30; 337-350.

Gontard, N. and Guilbert, S., 1996. Bio Packaging Technology and Properties of Edible And/Or Biodegradable Material of Agricultural Origin. In Food Packaging And Preservations. Blackie Academic And Professional, 159-181.

Grevellec, J., Marquie, C., Ferry, L., Crespy, A., Vialettes, V., 2001. Processability of cottonseed proteins into biodegradable materials, Biomacromolecules, 2: 1104-1109.

Hagenmaier, R.D. and Baker, R.A. 1994. Wax microemulsions and emulsions as citrus coatings. J. Agric. Food Chem. 42(4): 899-902.

Jahani, S., Kavoosi, G., Shakiba, A., 2014. Chemical and Biological Properties of Trachy spermumammien capsulated in Gelatin Nanofilms. International Journal Infect, 1(1); E18420.

Jeon, Y. I., Kamil, J.Y.V.A., Shahidi, F., 2002. Chitosan As an Edible Invisible Film for Quality Preservation of Herring and Atlantic Cod, J Agric Food Chem, 20; 5167-5178.

Jiang, M., Liu, S., Wang, Y., 2010. Effects of Antimicrobial Coating from Catfish Skin Gelatin on Quality and Shelf Life of Fresh White Shrimp (Penaeus vannamei), J Food Sci, 76(3); M204-M209.

Joukia, M., Mortazavia, S., Tabatabaei, Y. F., Koochekia, A., Khazaei, N., 2014. Use of Quince Seed Mucilage Edible Films Containing Natural Preservatives ToenhancephysicoChemical Quality of Rainbow Trout Fillets During Cold Storage. Food Science and Human Wellness, 3; 65-72.

Kandemir, N. S., 2006. Doğal antimikrobiyal madde içeren yenilebilir pullulan film uygulamanın hazır salatanın raf ömrüne etkileri, Yüksek lisans tezi, Ege Üniversitesi Fen Bilimleri Enstitüsü, İzmir.

Khanedan, N., Motalebi, A. A., Khanipour, A. A., Koochekiansabour, A., Seifzadeh, M.,

Kester, J. J. and Fennema, O., 1986. Edible films and coatings: A review. Food Technology. 40 (12), 47-59.

Kokangül, G. ve Fenercioğlu, H., 2012. Gıda endüstrisinde akıllı ambalaj kullanımı. Gida Teknolojileri Elektronik Dergisi 7(2): 31-43

Krochta, J. M., Baldwin, E. A., Nisperos-Carriedo, M. O., 1997. Edible Coatings and Films To Improve Food Quality. Technomic Publ. Co. Lancaster, Pa.

Krochta, J. M. and Mulder-Johnston, C. D., 1997. Edible and biodegradable polymer films: Challenges and Opportunities, Food Technology, 51 (2). 61-74.

Krochta, J. M., 2002. Proteins as raw materials for films and coatings: definitions, current status, and opportunities. In: Gennadios, A., editor). Protein-based films and coatings. Boca Raton, FL, USA: CRC Press. p. 1-41.
Lee, J. Y., Park, H. J., Lee, C. Y., Choi, W. Y., 2003. Extending shelflife of minimally processed apples with edible coatings and antibrowning agents. Lebensmittel Wissenschaft undTechnologie, 36, 323-329.

Lerdthanangkul, S. and Krochta, J. M., 1996. Edible coating effects on post harvest quality of green bell peppers. Journal of Food Science. 61: 176-179.

Lim, S. H., Hudson, S. M., 2003. Review of chitosan and its derivatives as antimicrobial agents and their uses as textile chemicals. Journal Macromol Science. 43, 223- 269.

Liu, C. C., Tellez-Garay, A. M., Castell-Perez, M. E., 2004. Physical and mechanical properties of peanut protein films, Lebensmittel Wissenschaft und Technologie, 37: 731-738.

Lu, F., Liu, D. H., Ye, X. Q., 2009. Alginate calcium coating incorporating nisin and EDTA maintains the quality of fresh northern snakehead (Channaargus) fillets stored at 4_C. Journal Science Food Agriculture 89, 848- 854.

Meenatchisundaram, S., 2016. Effect of Spice-Incorporated Starch Edible Film Wrapping on Shelf Life of White Shrimps Stored at Different Temperatures. J Sci Food Agric. 96 (12), 4268-4275. 2016 Feb 26.

Mohan, C. O., Ravishankar, C. N., Latitha, K. V., Srinivasa Gopal, T. K., 2012. Effect of Chitosan Edible Coating on The Quality of Double Filleted Indian Oil Sardine (Sardinella longiceps) During Chilled Storage. Food Hydrocolloids, 26 (1); 161-174.

Morillon, V., Debeaufort, F., Blond, G., Capelle, M., Voilley, A., 2002. Factors Affecting The Moisture Permeability of Lipid-Based Edible Films. Food Science Nutrient. 42(1); 67-89.

Motalebi A.A., Hasanzati Rostami A., Khanipour A.A., Soltani, M., 2010. Impacts of whey protein edible coating on chemical and microbial factors of gutted kilka during frozen storage. Iranian Journal of Fisheries Sciences 9(2): 255-264.

Noorihashemabad, Z., Ojagh, S. M., Alishahi, A., 2015. A comprehensive surviving on application and diversity of biofilms in seafood. International Journal of Biosciences. Vol. 6, No. 3, p. 15-30.

Orliac, O. and Silvestre, F., 2003. New thermomolded biodegradable films based on sunflower protein isolate: aging and physical properties, Macromoecular Symposia, 197: 193-206

Park, S.I., Marsh, K.S., Dawson, P., 2010. Application of chitosanincorporated LDPE film to sliced fresh red meats for shelf life extension. Meat Science 85(3): 493-499.

Placido, J. and Capareda, S., 2015. Ligninolytic enzymes: a biotechnological alternative for bioethanol production. Bioresources and Bioprocessing, 2(23):1-12.

Polat, H., 2007. İşlenmiş Et Ürünlerinde Yenilebilir Filmlerin ve Kaplamaların Uygulamaları. Yüksek Lisans Tezi, Afyon Kocatepe Üniversitesi, Fen Bilimleri Enstitüsü, Gıda Mühendisliği Anabilim Dalı, Afyon.

Raeisi, M., Tajik, H., Aliakbarlu, J., Valipour, S., 2014. Effect of Carboxymethyl Cellulose Edible Coating Containing Zataria multiflora Essential Oil and Grape Seed Extract on Chemical Attributes of Rainbow Trout Meat. Veterinary Research Forum, 5(2); 89-93.

Rhim, J. W., 2004. Physical and mechanical properties of water resistant sodium alginate films. Lebensmittel-Wissenschaft und-Technologie 37(3), 323-330.

Robertson, G.L., 2013. Food Packaging: Principle and Practice. Third Edition, CRC Press, Boca Raton, 703p.

Rollini, M. Nielsen, T. Musatti, A. Limbo, S. Piergiovanni, L. Munoz, P.H., Gavara, R., 2016. Antimicrobial Performance of Two Different Packaging Materials on the Microbiological Quality of Fresh Salmon. Coatings, 2016, 6,6 .

Saldamlı, I., 1985. G1da Katkı Maddeleri ve İngrediyenler. Önder Matbaas1, Ankara. 
Sallam, K.I., Ishioroshi, M., Samejima, K., 2004. Antioxidant and antimicrobial effects of garlic in chicken sausages. Lebensmittel-Wissenschaft und-Technologie 37(8): 849-855.

Sarığglu, T., 2005. Yenilebilir filmlerin kaşar peynirinin kaplanmasında kullanılma olanakları ve peynir kalitesi üzerine etkileri, Yüksek lisans tezi, Süleyman Demirel Üniversitesi Fen Bilimleri Enstitüsü, Isparta.

Sarıkuş, G., 2006. Farklı antimikrobiyal maddeler içeren yenilebilir film üretimi ve kaşar peynirinin muhafazasında mikrobiyal inaktivasyona etkisi, Yüksek lisans tezi, Süleyman Demirel Üniversitesi Fen Bilimleri Enstitüsü, Isparta.

Sathivel, S., 2005. Chitosan and protein coatings affect yield, moisture loss, and lipid oxidation of pink salmon (Oncorhynchus gorbuscha) fillets during frozen storage. Journal of Food Science 70(8): 455-459.

Shahidi, F., Abuzaytoun, R., 2005. Chitin, chitosan, and coproducts: chemistry, production, applications, and health effects. Advance Food Nutrient Research. 49, 93-135.

Shatalov, I., Shatalova, A., Shleikin, A., 2014. Development of Edible Packaging Material Based on Protein Film. Foodbalt, 298-301.

Shih, F. F., 1998. Film-forming properties and edible films of plant proteins, Nahrung, 42 (3/4): 254-256.

Song, Y., Liu, L., Shen, H., You, J., Luo, Y., 2011. Effect of sodium alginate-based edible coating containing different anti-oxidants on quality and shelf life of refrigerated bream (Megalobrama amblycephala). Food Control 22 (3-4): 608615.

Stuchell, I., Krochta, J., 1995. Edible Coatings on Frozen King Salmon: Effect of Whey Protein Isolates and Acetylated Monoglycerides on Moisture Loss and Lipid Oxidation. Journal Of Food Science, 60; 28-31.

Sürengil, G. ve Kılınç, B., 2011. Gıda ambalaj sektöründe nanoteknolojik uygulamalar ve su ürünleri açısından önemi. Journal of Fisheries Sciences 5 (4): 317-325.
Şahin, O. I. ve Bayizit, A. A., 2008. Nanokompozit filmlerin gıda sanayi uygulamaları. Türkiye 10. Gıda Kongresi, 21-23 Mayis, Erzurum.

Tammineni, N., Ünlü, G., Min S.C., 2013. Development of antimicrobial potato peel wastebased edible films with oregano essential oil to inhibit Listeria monocytogenes on cold-smoked salmon. International Journal of Food Science and Technology 48 (1): 211-214.

Temiz, H. ve Yeşilsu, A. F., 2006. Bitkisel protein kaynaklı yenilebilir film ve kaplamalar, Gida Teknolojisi Dergisi, 2: 41-50.

Tien, C. L., Letendre, M., Ispas-Szabo, P., Mateescu, M. A., Patterson, G. D., Yu, H. L, Lacroix, M., 2000. Development of biodegradable films from whey proteins by cross-linking and entrapment in cellulose. Journal of Agricultural and Food Chemistry. 48: 5566-5575.

Trius, A. and Sebranek, J. G., 1996. Carrageenans and their use in meat products. CRC Crit. Rev. Food Sci. Nutr., 36, 69-85.

Utami, R., Nurhartadi, E., Putra, A., Setiawan, A., 2014. The Effect of Cassava Starch-Based Edible Coating Enriched with Kaempferia Rotunda and Curcuma Xanthorrhiza essential Oil on Refrigerated Patin Fillets Quality. International Food Research Journal, 21; 413- 419.

Valdes, A., Mellinas, A. C., Ramos, M., Garrigos, M. C., Jimenez, A., 2014. Natural additives and agricultural wastes in biopolymer formulations for food packaging. Frontiers in chemistry $2,1-10$.

Vargas, M., Pastor, C., Chiralt, A., Mc Clements, D.J., GonzalezMartinez, C., 2008. Recent Advances in Edible Coatings for Fresh and Minimally Processed Fruits. Critical Reviews in Food Science and Nutrition, 48, 496-511.

Yamamoto, K., Igawa, K., Sugimoto, K., Yoshizawa, Y., Yanagiguchi, K., Ikeda, T., Yamada, S., Hayashi, Y., 2014. Biological Safety of Fish (Tilapia) Collagen. BioMed Research International.

Yıldız, P. O., 2017. Effect of Chitosan Coatings Enriched with Cinnamon Oil on Proximate Composition of Rainbow Trout Fillets. American Institute of Physics. 1833, 020070. 